\title{
Children hospitalized for myiasis in a reference center in Uruguay
}

\author{
Martín Notejane ${ }^{1,2 *}$, Cristina Zabala ${ }^{1,2}$, Lucía Ibarra ${ }^{2}$, Leticia Sosa ${ }^{2}$, and Gustavo Giachetto ${ }^{1,2}$ \\ ${ }^{1}$ Clínicas Pediátricas, Facultad de Medicina, Universidad de la República; ${ }^{2}$ Hospital Pediátrico, Centro Hospitalario Pereira Rossell. Montevideo, \\ Uruguay
}

\begin{abstract}
Background: Myiasis is an emerging disease caused by tissue invasion of dipteran larvae. In Uruguay, Cochliomyia hominivorax and Dermatobia hominis are the most frequent species. This study aimed to describe the epidemiological and clinical characteristics and the follow-up of children < 15 years hospitalized for myiasis in a reference center in Uruguay between 2010 and 2019. Methods: We conducted a descriptive and retrospective study by reviewing medical records. We analyzed the following variables: age, sex, comorbidities, origin, the month at admission, clinical manifestations, other parasitoses, treatments, complications, and larva species identified. Results: We found 63 hospitalized children: median age of 7 years (1 month-14 years), $68 \%$ of females. We detected risk comorbidities for myiasis (33\%), of which chronic malnutrition was the most frequent $(n=6) ; 84 \%$ were from the south of the country; $76 \%$ were hospitalized during the summer. Superficial and multiple cutaneous involvements were found in $86 \%$ : of the scalp 50, furunculoid type 51 , secondary to C. hominivorax $98.4 \%$, and to D. hominis in $1.6 \%$. As treatments, larval extraction was detected in all of them, surgical in $22 \%$. Asphyctic products for parasites were applied in 94\%, ether in 49. Antimicrobials were prescribed in 95\%; cephradine and ivermectin were the most frequent. About $51 \%$ presented infectious complications: impetigo was found in 29, cellulitis in 2 , and abscess in 1. Conclusions: Myiasis predominantly affected healthy schoolchildren during the summer months and was frequently associated with ectoparasites. Superficial infestation of the furuncle-like scalp by C. hominivorax was the most frequent form. Infectious complications motivated hospitalizations.
\end{abstract}

Keywords: Myiasis. Larva. Parasitosis. Cochliomyia hominivorax. Ivermectin. Children.

\section{Niños hospitalizados por miasis en un centro de referencia de Uruguay Resumen}

Introducción: La miasis es una enfermedad emergente producida por la invasión tisular por larvas de dípteros. En Uruguay, Cochliomyia hominivorax y Dermatobia hominis son las especies más frecuentes. El objetivo de este estudio fue describir las características epidemiológicas y clínicas, y el seguimiento, de niños menores de 15 años hospitalizados por miasis en un centro de referencia del Uruguay entre 2010 y 2019. Métodos: Se llevó a cabo un estudio descriptivo y retrospectivo mediante la revisión de las historias clínicas. Se analizaron las siguientes variables: edad, sexo, comorbilidad, procedencia, mes al ingreso, cuadro clínico, otras parasitosis, tratamientos, complicaciones y especie de larva identificada.

Correspondence:

*Martín Notejane

E-mail: mnotejane@gmail.com
Date of reception: $30-07-2020$

Date of acceptance: 17-02-2021

DOI: 10.24875/BMHIM.20000236
Available online: 23-07-2021

Bol Med Hosp Infant Mex. 2021;78(4):287-292

www.bmhim.com

1665-1146/C 2021 Hospital Infantil de México Federico Gómez. Published by Permanyer. This is an open access article under the CC BY-NC-ND license (http://creativecommons.org/licenses/by-nc-nd/4.0/). 
Resultados: Se encontraron 63 casos de niños hospitalizados, con una mediana de edad de 7 años (rango: 1 mes a 14 años) y el $68 \%$ de sexo femenino. Se identificó comorbilidad de riesgo para miasis (33\%), siendo la desnutrición crónica la más frecuente $(n=6)$. El $84 \%$ eran procedentes del sur del país y el $76 \%$ fueron hospitalizados en los meses estivales. Se encontró afectación cutánea superficial y múltiple en el $86 \%$ : de cuero cabelludo en 50 , de tipo forunculoide en 51 , secundaria a C. hominivorax en el $98.4 \%$ y a D. hominis en el 1.6\%. Se realizó extracción larvaria en todos los casos, que fue quirúrgica en el 22\%. Se aplicaron productos asfícticos para parásitos en el 94\%, con éter en 49 niños. Se prescribieron antimicrobianos en el $95 \%$; los más usados fueron cefradina e ivermectina. El 51\% presentaron complicaciones infecciosas: 29 impétigo, 2 celulitis y 1 absceso. Conclusiones: La miasis afectó predominantemente a escolares sanos y durante los meses estivales, y se encontró frecuentemente asociada con ectoparasitosis. La infestación superficial del cuero cabelludo de tipo forunculoide por C. hominivorax fue la forma más frecuente. Las complicaciones infecciosas motivaron las hospitalizaciones.

Palabras clave: Miasis. Larva. Parasitosis. Cochliomyia hominivorax. Ivermectina. Niños.

\section{Introduction}

Myiasis refers to a lesion produced by dipteran larvae that infest animals, including humans, and feed in a parasitic manner. This condition can cause lesions and tissue damage of varying severity with risk of cosmetic sequelae, infectious complications, and psychoemotional problems ${ }^{1-4}$.

In recent years, myiasis has been considered an emerging disease. This situation could be linked to population increase, disorganized urbanization, and the introduction of the fly into the forest habitat ${ }^{1,2,5,6}$. The etiologic agents vary according to geographic location. In tropical Africa, the principal etiologic agent is Cordylobia anthropophaga, while in the Americas is Dermatobia hominis and Cochliomyia hominivo$\operatorname{rax}^{1,3,5-11}$. C. hominivorax, the principal agent of myiasis in Uruguay, is popularly known as the "bichera" or "cattle screwworm fly"12,13. A study conducted by the Dirección General de Servicios Ganaderos (DGSG, General Directorate of Livestock Services) in 2006 on the effect of $C$. hominivorax on national livestock production determined a prevalence of $5.7 \%$ in sheep and $3.4 \%$ in cattle, with economic repercussions of more than 38 million dollars/year. They also reported the presence of approximately 818 cases per year of myiasis in humans ${ }^{14}$.

The diagnosis of myiasis is clinical; it requires an adequate anamnesis inquiring about the history of previous comorbidities that may favor larval infestation and the person's origin and recent travels. The clinical examination should describe the type of lesion produced and macroscopically identify specimens of the pathogenic larva $2,3,7,10$.

The most common clinical presentation in pediatrics is cutaneous myiasis of the furunculoid type, characterized by a reddish, pruritic, inflamed nodule with a small orifice that allows air to enter the larval spiracles. The traumatic form or "wound myiasis" follows in frequency and is due to the invasion of cutaneous lesions, secondary to the presence of other ectoparasites or dermatitis that favor scratching and epidermal rupture ${ }^{1-10}$.

Research on this subject is scarce in pediatrics. Further study of children hospitalized for myiasis could contribute to its prevention and improved treatment.

This study aimed to describe the epidemiological, clinical, and follow-up characteristics of children $<15$ years of age hospitalized for myiasis between 2010 and 2019 in a referral center in Uruguay.

\section{Methods}

We conducted a descriptive and retrospective study by reviewing medical records. All children under 15 years of age hospitalized for myiasis at the Hospital Pediátrico, Centro Hospitalario Pereira Rossell (HP-CHPR) between January 1, 2010, and December 31,2019 , were included. We elaborated a data collection form. The variables analyzed were age, sex, comorbidities associated with myiasis, origin, the month of admission, clinical manifestation, concurrent parasitosis, complications, complementary studies, treatments, hospital stay, and mortality. Regarding the myiasis agent, larvae species were identified and recorded.

For this study, "deep or cavitated myiasis" was defined as that located in the oral cavity, nasopharynx, ear canal, rectal, or vulvovaginal areas.

Qualitative variables were expressed in absolute (n) and relative frequencies (\%), whereas quantitative variables, in central tendency measures and range. Microsoft Excel 2016 was used to process the data.

The study was approved by the Direction and the Research Ethics Committee of the HP-CHPR. 
Table 1. Characteristics of children hospitalized for myiasis

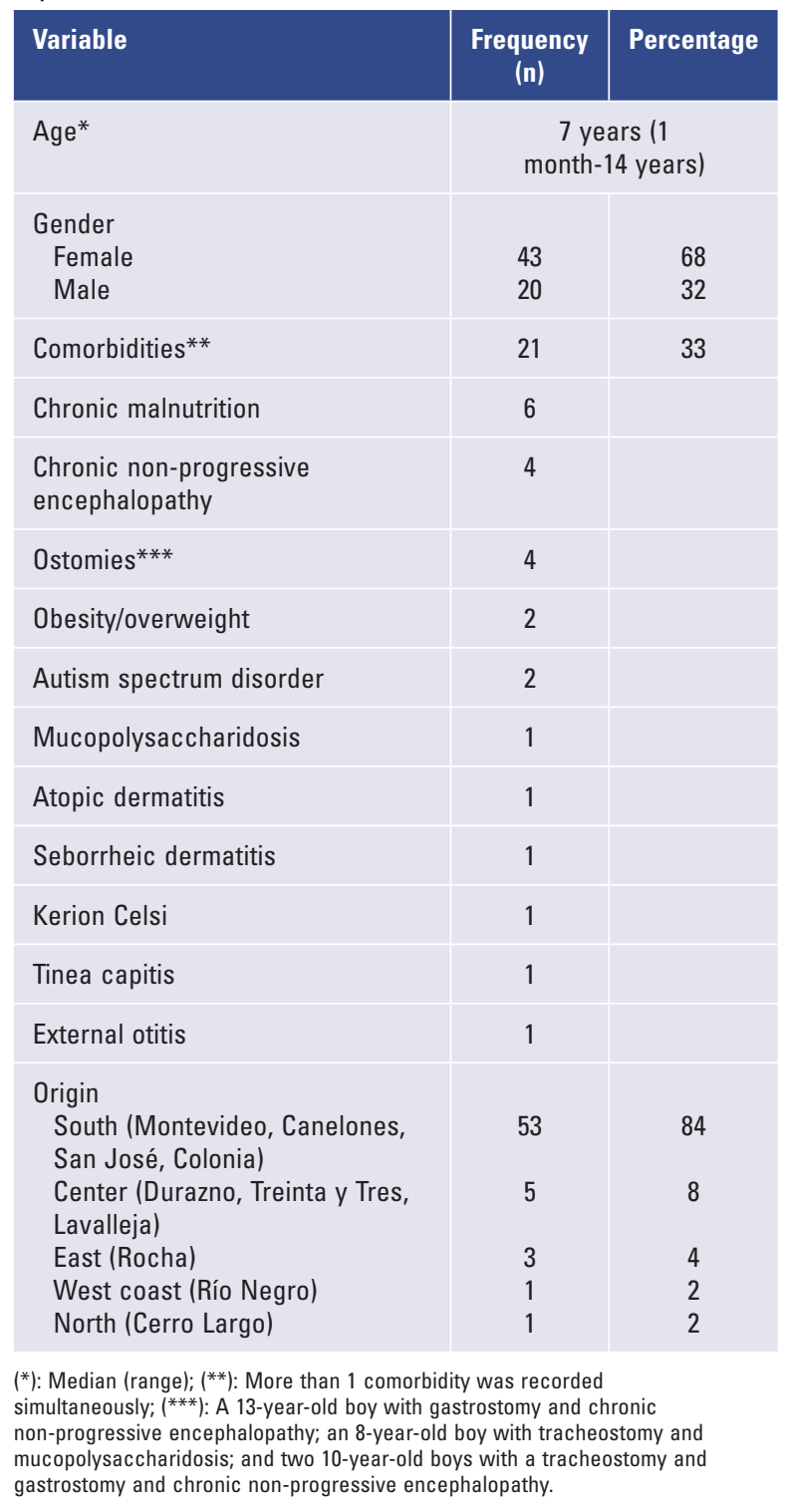

\section{Results}

Sixty-three children were hospitalized for myiasis; the discharge rate was $5.92 / 10,000$ in the study period. The median age was 7 years (range 1 month-14 years), and $68 \%$ were female $(n=43)$. One-third of the patients presented comorbidities $(n=21)$; chronic malnutrition was the most frequent $(n=6)$. Furthermore, $84 \%$ of patients came from the south of the country $(n=53)$, and $76 \%$ were hospitalized during the summer months $(n=48)$. Table 1 shows the characteristics of the included population. Fig. 1 shows the distribution of hospital admissions by month.

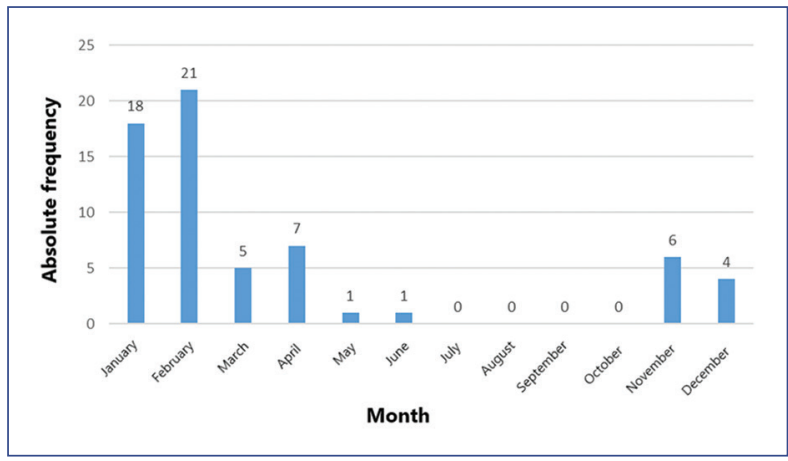

Figure 1. Monthly distribution of myiasis hospitalizations (2010-2019).

Superficial cutaneous myiasis was recorded in $86 \%$ of patients $(n=54)$, located on the scalp $(n=50)$, and forunculoid type $(n=51)$. In $48 \%$, they were associated with other parasitosis $(n=30)$, mostly pediculosis $(\mathrm{n}=27)$. Skin and soft-tissue infections were observed in $51 \%$ of patients $(n=32)$ at hospital admission, mostly impetigo $(n=29)$. Table 2 shows the clinical characteristics and complications.

Additional studies were requested in $36.5 \%$ of the patients $(n=23)$, including hemogram and acute-phase reactants $(n=12)$; eosinophilia was found in eight patients. Myiasis agents were clinically identified: C. hominivorax in $98 \%(\mathrm{n}=62)$ and $D$. hominis in $1.6 \%$ $(n=1)$. Figure $2 A$ and $B$ shows a furunculoid cutaneous myiasis of the scalp with multiple larvae of $C$. hominivorax. Figure $3 A$ and $B$ shows a single furunculoid cutaneous myiasis with $D$. hominis larvae located on the scapula.

Manual removal of larvae was performed in all the patients, of which $22 \%(n=14)$ required admission to the surgical block for cleaning and removal. Asphyxial treatment for parasite removal was applied in 94\% $(n=59)$, using ether $(n=49)$ among other substances. Antimicrobials were prescribed in $95 \%$ of the cases $(n=60)$, mostly orally $(n=52)$. The most commonly used antimicrobials and antiparasitic were cephradine $(n=32)$ and oral ivermectin $(n=14)$ (Table 3).

The median hospital stay was 3 days (range 2-11). Only one readmission for further larval extraction was recorded. No deaths were recorded.

\section{Discussion}

In this series, the hospitalization rate for myiasis was low, although previous data were not available. Due to this pathology, the real morbidity rate may be 
Table 2. Clinical characteristics and complications of children hospitalized for myiasis

\begin{tabular}{|c|c|c|}
\hline Variables & $\begin{array}{l}\text { Frequency } \\
\text { (n) }\end{array}$ & Percentage \\
\hline Superficial skin topography* & 54 & 86 \\
\hline Scalp & 50 & \\
\hline Upper back & 3 & \\
\hline Neck (peri-tracheostomy) & 2 & \\
\hline Abdomen (peri-gastrostomy) & 2 & \\
\hline Lower limbs & 1 & \\
\hline Cavitated or deep topography* & 9 & 14 \\
\hline Ear canal (aural) & 5 & \\
\hline Oral cavity & 2 & \\
\hline Tonsillar & 2 & \\
\hline Type of lesion & & \\
\hline Forunculoid & 51 & 81 \\
\hline $\begin{array}{l}\text { Traumatic or secondary to skin } \\
\text { injury }\end{array}$ & 12 & 19 \\
\hline Associated parasites* & 30 & 48 \\
\hline Pediculosis & 27 & \\
\hline Scabies & 6 & \\
\hline Oxyuriasis & 2 & \\
\hline Toxocariasis & 1 & \\
\hline Infectious complications & 32 & 51 \\
\hline Impetigo & 29 & \\
\hline Cellulitis & 2 & \\
\hline Abscess & 1 & \\
\hline
\end{tabular}

underestimated since most cases of myiasis in children are resolved in the outpatient clinic and not associated with complications ${ }^{1,2,12,14}$. Consistent with other previously reported series, a high prevalence of hospitalizations for myiasis was observed during the summer months, which are related to the vector cycle, high temperatures, rains, and floods that favor the growth and development of flies ${ }^{14}$.

The following factors have been described as risk factors or factors favoring the appearance of myiasis: age under 1 year, residence in tropical or subtropical geographical areas, invasion of the fly's natural habitat, socioeconomic and cultural vulnerability, inadequate hygienic habits, presence of comorbidities affecting mobility such as cerebral palsy or other neurological diseases, use of prostheses, ostomies, the coexistence of other ectoparasites, presence of dermatitis, tinea, or other skin lesions. In this study, the most affected were school age children; one-third of the cases presented

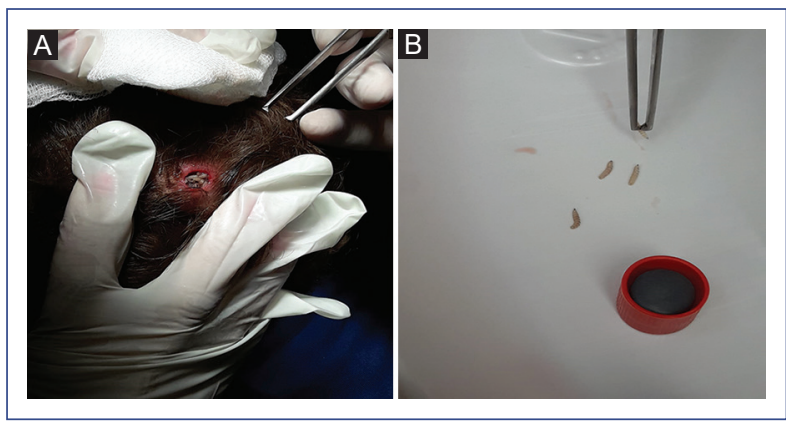

Figure 2. A: scalp myiasis. B: larvae of Cochliomyia hominivorax.

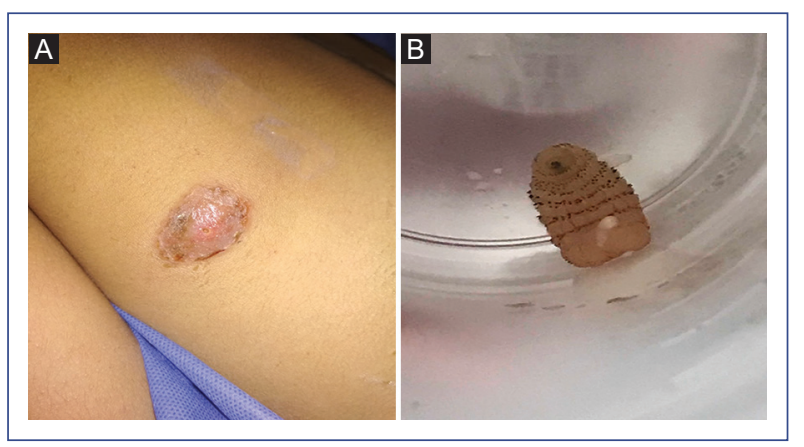

Figure 3. A: single furunculoid cutaneous myiasis. B: larvae of Dermatobia hominis.

comorbidities or factors favoring myiasis. Among these factors, we found chronic malnutrition, neurological diseases, prosthesis use, or having an ostomy. It is important to note that children assisted by this health-care system represent the most vulnerable population in the country2-4,6-10.

Myiasis can be classified according to its topography as cutaneous (furunculoid, tumorous, and serpiginous), cavitary, or deep (oral, nasopharyngeal, aural, anorectal, and vulvovaginal $)^{1-7}$. In this study, cutaneous myiasis of the scalp of the furunculoid type predominated. The presence of atopic dermatitis, seborrheic dermatitis, tinea, or kerion Celsi, as well as the concomitance with pediculosis or scabies, can favor infestation by larvae. One-third of the hospitalized children presented some ectoparasites, of which pediculosis was the most frequent ${ }^{1-8,15}$.

The involvement of natural cavities such as the ear canal, oral cavity, orbit, or nostrils is rare but potentially critical. One of the children included in this study presented oral involvement. The patient was a 13-year-old adolescent with chronic non-progressive 
Table 3. Complementary studies and treatment

\begin{tabular}{|c|c|c|}
\hline Variables & $\begin{array}{l}\text { Frequency } \\
\text { (n) }\end{array}$ & Percentage \\
\hline Complementary studies* & 23 & 36.5 \\
\hline $\begin{array}{l}\text { Hemogram and acute-phase } \\
\text { reactants }\end{array}$ & 12 & \\
\hline Skin exudate & 6 & \\
\hline Blood culture & 4 & \\
\hline Skin and soft-tissue ultrasound & 3 & \\
\hline Ova and parasite test & 3 & \\
\hline Tape test & 3 & \\
\hline Toxocara serology & 3 & \\
\hline Eye fundus examination & 3 & \\
\hline Cranial tomography & 1 & \\
\hline $\begin{array}{l}\text { Treatments* } \\
\text { Parasite removal } \\
\text { Removal and surgical cleaning } \\
\text { Asphyxiating agents** } \\
\text { Ether } \\
\text { Vaseline } \\
\text { Povidone-iodine } \\
\text { Bacon } \\
\text { Antimicrobials* } \\
\text { Cephradine } \\
\text { Clindamycin } \\
\text { Amoxicillin-clavulanic acid } \\
\text { Trimethoprim-sulfamethoxazole }\end{array}$ & $\begin{array}{c}63 \\
14 \\
59 \\
49 \\
5 \\
3 \\
3 \\
60 \\
32 \\
29 \\
8 \\
2\end{array}$ & $\begin{array}{c}100 \\
22 \\
94\end{array}$ \\
\hline $\begin{array}{l}\text { Antiparasitic } \\
\text { Permethrin 2\% } \\
\text { Ivermectin } \\
\text { Mebendazole }\end{array}$ & $\begin{array}{c}21 \\
14 \\
3\end{array}$ & \\
\hline
\end{tabular}

$\left({ }^{*}\right)$ : Complementary studies and multiple treatments were recorded; $\left({ }^{* *}\right)$ : The asphyxiating agents used (prehospital and hospitalization) were recorded.

encephalopathy secondary to central nervous system malformations. In these cases, the permanent oral aperture and the presence of dental septic foci constitute risk factors for myiasis $2,4,8,15,16$.

The identified myiasis vectors in this study coincide with the national and regional literature, with $C$. hominivorax being the principal agent of animal and human myiasis from southern Colombia to North Argentina and some Caribbean islands. At present, vector eradication programs have eliminated cases in Panama, and cases are rare in Chile-3,6-8,12-14. C. hominivorax is referred to as one of the most aggressive agents because it can invade open lesions or natural orifices and destroy cartilage and bones, causing severe and even fatal complications. This myiasis agent has the particularity of depositing large quantities of eggs, generating a high concentration of larvae; also, it has a predilection for infesting natural cavities such as the nostrils, mouth, ear canal, or orbits ${ }^{1-3,5,7,8,15,16}$.

In most of the children, manual removal of the larvae was performed. Except for those cases with oral involvement, parasite asphyxiating agents were used. Ether was the most commonly used asphyxiating agent, consistent with the literature, although, in situations of massive infestation, parasite death can make extraction difficult, requiring invasive surgical procedures. A significant number of cases requiring exploration and surgical cleaning were recorded in this study. The possible causes were late consultation, the consequent migration of the larvae to deeper planes, and the pathogenic mechanism of $C$. hominivorax itself ${ }^{1-8,17-19}$. The manual removal of larvae is a minimally painful procedure but generates much anxiety in the child and family, especially in cases of cephalic involvement. These procedures should be performed under sedation analgesia, according to each institution's protocols.

There is no international consensus regarding topical or systemic treatment with ivermectin; most authors recommend its use in severe or massive cases or furunculoid myiasis with single larvae. Ivermectin selectively binds to glutamate-regulated chloride channels of parasites' nerve and muscle cells, increasing their permeability and causing paralysis and death. In this series, ivermectin was prescribed in 14 cases: to treat associated parasitosis (scabies or pediculosis) in five cases and due to deep or cavitated myiasis in nine cases $^{1-5,8,17-23}$.

The most frequently recorded complications were skin and soft-tissue infections, which occurred in onethird of the cases, mainly impetigo. However, antibiotics were prescribed empirically in most of the children. It is of fundamental importance to perform a correct clinical evaluation for the rational use of antibiotics since, in the vast majority of cases, myiasis is clean lesions ${ }^{1-10}$.

The diagnosis of myiasis and skin and soft-tissue infection is clinical. In some cases, the use of soft-tissue ultrasound may be helpful to rule out differential diagnoses (sebaceous cysts, bacterial furuncles, cat scratch disease, leishmaniasis, among others) $)^{1,9}$.

Mortality reported for this disease is $<10 \%$, generally associated with encephalic involvement, aural myiasis, and nasal myiasis due to C. hominivorax. No fatal cases were observed in this series ${ }^{1-4,10}$.

Myiasis is a potentially preventable disease through mosquito nets, repellents, appropriate clothing, wound 
management and coverage, and personal hygiene. Other measures are aimed at vector control. The application of genetic bioengineering stands out to develop the "sterile insect technique," which involves releasing sterile males into the ecosystem. This method has enabled many countries to eradicate human and animal cases of myiasis caused by $C$. hominivorax ${ }^{3,17-24}$. It is essential to deepen prevention measures and develop strategies at the public health level to understand local epidemiology better and improve vector control strategies $^{12,14,24}$.

In conclusion, myiasis mostly affected healthy schoolchildren; hospitalizations occurred predominantly during summer months and were frequently associated with other ectoparasites. Superficial infestation of the scalp of the furunculoid type by $C$. hominivorax was the most frequent form. Infectious complications led to hospitalizations. It is necessary to improve vector prevention and control measures.

\section{Ethical disclosures}

Protection of human and animal subjects. The authors declare that no experiments were performed on humans or animals for this study.

Confidentiality of data. The authors declare that they have followed the protocols of their work center on the publication of patient data.

Right to privacy and informed consent. The authors have obtained the written informed consent of the patients or subjects mentioned in the article. The corresponding author has this document.

\section{Conflicts of interest}

The authors declare no conflicts of interest.

\section{Funding}

None.

\section{References}

1. Zúñiga I, Lozano J. Miasis: un problema de salud poco estudiado en México. Rev Enferm Infecc Pediatr. 2009;22:121-5.

2. Reinoso-Quezada S, Alemán-Iñiguez JM. Rara miasis maxilar por Cochliomyia hominivorax. Reporte de caso, actualidad y entomología. Rev Esp Cir Oral Maxilofac. 2016;38:111-6.

3. Calderón P, Rojas C, Apt W, Castillo D. Miasis cutánea por Cochliomyia hominivorax asociada a dermatitis seborreica. Rev Med Chile. 2017;145:250-4.

4. Menghi $\mathrm{Cl}$, Gatta CL, Oliva A. Otomiasis por Cochliomyia hominivorax en dos niños del conourbano bonaerense, Argentina. Rev Arg Microbiol. 2010;42:176-8.

5. Özkol HU, Calka O. Furuncle persistent to long-term antibiotic therapy in a non-tropical region: a diagnosis that must not be overlooked: furuncular cutaneous myiasis. Turkiye Parazitol Derg. 2014;38:138-40.

6. Belda-Hofheinz S, Guillén-Martín S, Pérez-Campos D, Rasero-Ponferrada M, Ramos-Amador JT, Salto-Fernández E. Miasis del cuero cabelludo en niño inmigrante. An Pediatr (Barc). 2003;59:114-6.

7. Failoc-Rojas VE, Silva-Díaz H. Review of cases and patient report of myiasis with tracheostomy, Peru. Emerg Infect Dis. 2016;22:563-5.

8. Blejter J. Tracheostomy wound myiasis in a child: case report and review of the literature. Case Rep Pediatr. 2012;2012:317862.

9. Rivera JI, Figueroa JM, Vicuña Cl, Rivera ME. Miasis en la colostomía de un lactante. Rev Chil Cir. 2017;69:281-2.

10. Raffo-Lirios M, Torres R. Miasis oral. Salud Milita. 2012;31:21-4.

11. Burgos FA, lölster T. Shock séptico secundario a miasis. Arch Argent Pediatr. 2001;99:271-2.

12. Valledor MS, Petraccia L, Cabral P, Castro O, Décia L, Xavier V, et al. Resultados del Diagnóstico de Bicheras Obtenidas en el Departamento de Artigas Durante 13 Semanas (Enero-abril 2009). Sextas Jornadas Técnicas, Facultad de Veterinaria. Uruguay: Universidad de la República; 2009. p. 130-1.

13. Martínez M, Remedios M, Goñi B. Lista de los Calliphoridae (Diptera: Muscomorpha) del Uruguay. Bol Soc Zool Uruguay. 2016;25:38-51.

14. Instituto Nacional de Investigación Agropecuaria. Estudio epidemiológico de las miasis cutáneas a Cochliomyia hominivorax en el Uruguay. Serie FPTA-INIA 82. Montevideo: Dirección General de Servicios Ganaderos, Ministerio de Ganadería, Agricultura y Pesca; 2019. pp.1-84. Available from: http://www.ainfo.inia.uy.

15. Domínguez-Enríquez J, Cueva-Rosillo J, Cusco-Cuzco C Rodríguez-Hidalgo R, Calvopiña M. Miasis orbitaria severa causada por Cochliomyia hominivorax en la región andina de Ecuador. Rev Mex Oftalmol. 2016:90:43-7.

16. Arenas-Rojas AM, Barajas-Ramírez NA. Miasis oral en un paciente adolescente con déficit neurológico crónico. Med UIS. 2015;28:381-5.

17. Landehag J, Skogen A, Asbakk K, Kan B. Human myiasis caused by the reindeer warble fly, Hypoderma tarandi, case series from Norway, 2011 to 2016. Eur Surveill. 2017;22:30576.

18. Lachish T, Marhoom E, Mumcuoglu KY, Tandlich M, Schwartz E. Myiasis in travelers. J Travel Med. 2015;22:232-6.

19. Mengarelli $\mathrm{RH}$, Cevallos MV. Manejo de las miasis en heridas agudas y crónicas. Presentación de casos y revisión de la bibliografía. Rev Argent Dermatol. 2012;93:1-8.

20. de Hollanda RA, Silva RA, Zaracho G. Ivermectina en el tratamiento de la miasis humana. An Fac Cienc Méd (Asunción). 2005;38:62-71.

21. Allevato MA. Miasis. Act Terap Dermatol 2005;28:272-9.

22. Garlatti ML, Font AM, Vacas AS, Guevara GP, Piva MM, Enz $P$, et al. Serie parasitosis en dermatología. Miasis: diferentes formas de presentación clínica. Rev Hosp Ital B Aires. 2017;37:34-8.

23. Asociación Española de Pediatría. Pediamécum. Madrid: Comité de Medicamentos; 2015. Available from: http://www.aeped.es.

24. Instituto Nacional de Investigación Agropecuaria. Situación Miasis 2019 Estudios epidemiológicos de las miasis cutáneas a Cochliomyia hominivorax en el Uruguay. Montevideo: Reunión CONASHS, Proyecto de Instituto Nacional de Investigación Agropecuaria FPTA 334; 2019. Available from: http://www.mgap.gub.uy. 